\title{
DEC 191995
}

\section{OSTI}

SITE STATUS MONITORING REPORT FOR UNDERGROUND STORAGE TANK 0134-U AT BUILDING 9204-2

\author{
OAK RIDGE Y-12 PLANT \\ OAK RIDGE, TENNESSEE \\ FACILITY ID \#0-010117
}

September 1995

Environmental Management Department Health, Safety, Environment, and Accountability Organization 


\section{DISCLAIMER}

This report was prepared as an account of work sponsored by an agency of the United States Government. Neither the United States Government nor any agency thereof, nor any of their employees, makes any warranty, express or implied, or assumes any legal liability or responsibility for the accuracy, completeness, or usefulness of any information, apparatus, product, or process disclosed, or represents that its use would not infringe privately owned rights. Reference herein to any specific commercial product, process, or service by trade name, trademark, manufacturer, or otherwise, does not necessarily constitute or imply its endorsement, recommendation, or favoring by the United States Government or any agency thereof. The views and opinions of authors expressed herein do not necessarily state or reflect those of the United States Government or any agency thereof.

\section{SCIENCE APPLICATIONS INTERNATIONAL CORPORATION}

contributed to the preparation of this document and should not be considered an eligible contractor for its review. 


\section{DISCLAIMER}

Portions of this document may be illegible electronic image products. Images are produced from the best available original document. 


\section{SITE STATUS MONITORING REPORT FOR UNDERGROUND STORAGE}

TANK 0134-U

AF BUILDING 9204-2

OAK RIDGE Y-12 PLANT

OAK RIDGE, TENNESSEE

FACILITY.ID \#0-010117

September 1995

Environmental Management Department

Health, Safety, Environment, and Accountability Organization

\section{Prepared by}

Science Applications International Corporation

Under Subcontract 22B-99069C

for the

Oak Ridge Y-12 Plant

Oak Ridge, Tennessee 37831

Managed by

Lockheed Martin Energy Systems, Inc.

for the

U.S. Department of Energy

Under Contract No. DE-AC05-84OR21400 


\section{TABLE OF CONTENTS}

Page

LIST OF FIGURES $\ldots \ldots \ldots \ldots \ldots \ldots \ldots \ldots \ldots \ldots \ldots \ldots \ldots \ldots \ldots$ iv

LIST OF TABLES $\ldots \ldots \ldots \ldots \ldots \ldots \ldots \ldots \ldots \ldots \ldots \ldots$ iv

LIST OF ACRONYMS $\ldots \ldots \ldots \ldots \ldots \ldots \ldots \ldots \ldots \ldots \ldots \ldots$ v

SIGNATURE PAGE $\ldots \ldots \ldots \ldots \ldots \ldots \ldots \ldots \ldots \ldots \ldots \ldots \ldots \ldots \ldots$ vi

CERTIFICATION PAGE $\ldots \ldots \ldots \ldots \ldots \ldots \ldots \ldots$ vii

\section{SITE STATUS MONITORING REPORT}

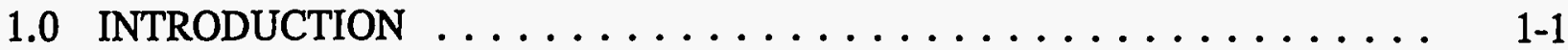

1.1 PURPOSE AND SCOPE $\ldots \ldots \ldots \ldots \ldots \ldots \ldots \ldots \ldots \ldots \ldots \ldots$

1.2 SITE DESCRIPTION $\ldots \ldots \ldots \ldots \ldots \ldots \ldots \ldots \ldots \ldots \ldots \ldots \ldots$

2.0 GROUNDWATER MONITORING $\ldots \ldots \ldots \ldots \ldots \ldots \ldots \ldots \ldots . \ldots \ldots$ 2-1

2.1 GROUNDWATER MEASUREMENT, SAMPLE COLLECTION,

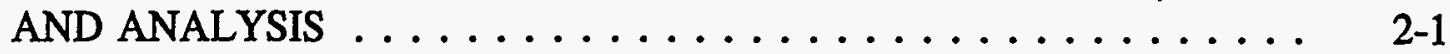

2.1 .1 Well Locations .................... 2-1

2.1.2 Groundwater Measurement and Sampling ......... 2-1

2.1.3 Sample Analysis .................. 2-1

2.2 POTENTIOMETRIC DATA $\ldots \ldots \ldots \ldots \ldots \ldots \ldots \ldots . \ldots \ldots$ 2-3

2.3 GROUNDWATER ANALYTICAL DATA $\ldots \ldots \ldots \ldots \ldots . \ldots 2-3$

3.0 VAPOR MONITORING $\ldots \ldots \ldots \ldots \ldots \ldots \ldots \ldots \ldots \ldots$ 3-1

3.1 MONITORING METHODS AND LOCATIONS $\ldots \ldots \ldots \ldots \ldots$ 3-1

3.2 VAPOR MONITORING RESULTS $\ldots \ldots \ldots \ldots \ldots \ldots \ldots \ldots$. $3-1$

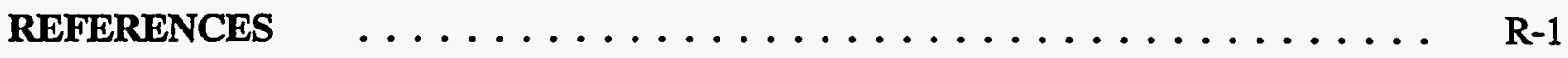

APPENDICES

APPENDIX A LABORATORY ANALYTICAL RESULTS FOR

SITE STATUS MONITORING GROUNDWATER SAMPLING . A-1 


\section{LIST OF FIGURES}

Figure Title

1-1 Location of the Building 9204-2 Site at the Oak Ridge Y-12 Plant . . . . . 1-2

1-2 Building 9204-2 Site Map . . . . . . . . . . . . . . . 1-3

2-1 Location of Groundwater Monitoring Wells at the Building 9204-2 Site . . 2 2-2

2-2 Building 9204-2 Site Groundwater Potentiometric Contour Map, March 1995 . . . . . . . . . . . . . . . . . . . . . . 2-4

2-3 Building 9204-2 Site Groundwater Potentiometric Contour Map, September $1995 \ldots \ldots \ldots \ldots \ldots \ldots$. . . . . . . . . . . . . . .

3-1 Organic Vapor Monitoring Points at the Building 9204-2 Site $\ldots \ldots \ldots$ 3-2

\section{LIST OF TABLES}

Table Title Page

2-1 Water Level Measurements at the Building 9204-2 Site for the Periods of September 1995 and March 1995 . . . . . . . . . . . . . . . 2-4

2-2 Analytical Results for Groundwater Samples Collected during Site Status and Comprehensive Monitoring, Site Ranking, and Baseline Sampling . . . 2-7

3-1 Vapor Monitoring Results for the Building 9204-2 Site, August 31, 1995 . . 3-1 


\section{LIST OF ACRONYMS}

BGS below ground surface

BTEX benzene, toluene, ethylbenzene, and xylenes

CAP Corrective Action Plan

Energy Systems Lockheed Martin Energy Systems, Inc.

LEL

TDEC lower explosive limit

TGD

TPH-GRO UEFPC

UST

$\Sigma$ BTX Tennessee Department of Environment and Conservation Technical Guidance Document total petroleum hydrocarbons-gasoline range organics Upper East Fork Poplar Creek underground storage tank total benzene, toluene, and xylenes 


\section{SIGNATURE PAGE}

\section{SITE STATUS MONITORING FOR THE BUILDING 9204-2 SITE}

I certify under penalty of law, including but not limited to penalties for perjury, that the information contained in this report and on any attachments, is true, accurate, and complete to the best of my knowledge, information, and belief. I am aware that there are significant penalties for submitting false information, including the possibility of fine and imprisonment for intentional violations.

See Attached Certification Owner/Operator (Print)

$\overline{\text { Signature }} \quad \overline{\text { Date }}$

P.E. or P.G. (Print)

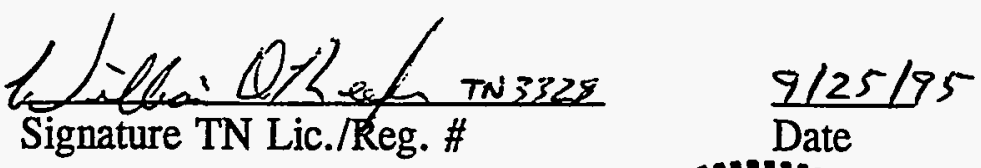

If a P.E. signs this report, please indicate the area of expertise.

(Print or Type)

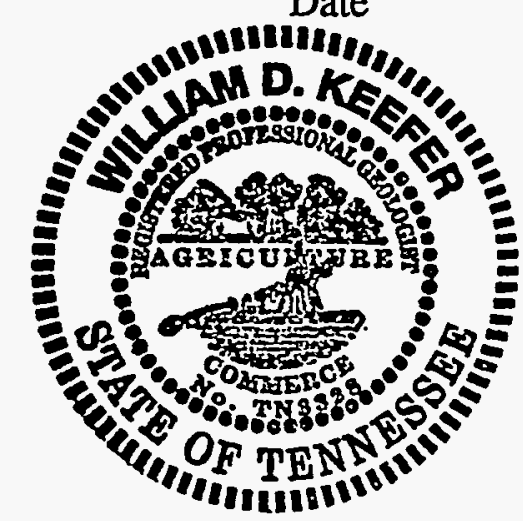

(P.E./P.G. Stamp/Seal)

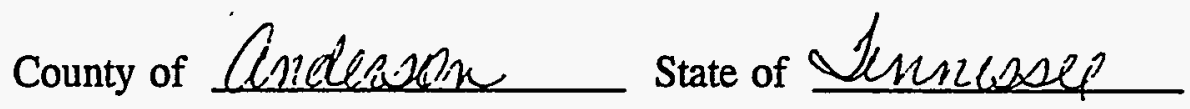

Subscribed and Sworn to before me this

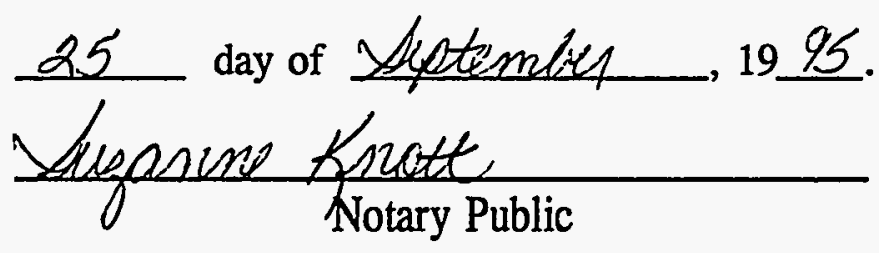

My Commission expires: $21-27-96 \quad$ (Notary Seal) 


\section{CERTIFICATION STATEMENT}

\section{SITE STATUS MONITORING FOR THE BUILDING 9204-2 SITE FACILITY ID 0-010117}

I certify that this document and all enclosures were prepared under my direction or supervision in accordance with a system designed to ensure that qualified personnel properly gather and evaluate the information submitted. Based on my inquiry of the person or persons directly responsible for gathering the information, the information submitted is, to the best of my knowledge and belief, true, accurate, and complete.

U.S. Department of Energy

Owner and Operator

By:
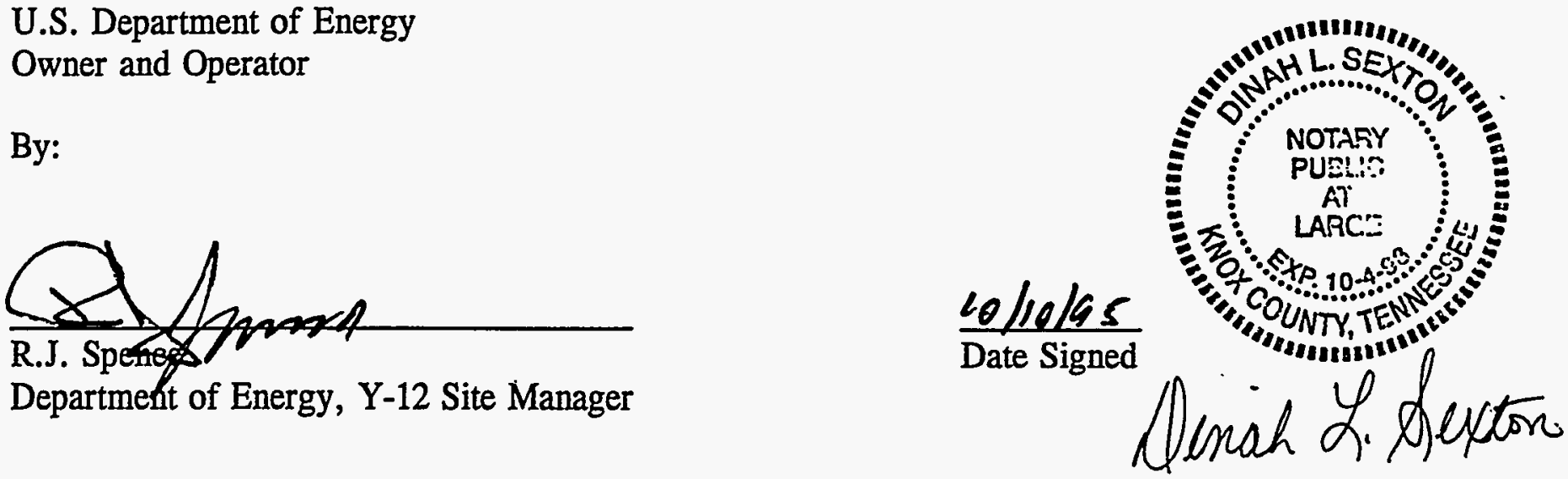

Lockheed Martin Energy Systems, Inc.

Co-Operator

By:

\section{Jn $2=$}

T.R. Butz

Lockheed Martin Energy Systems, Inc. Y-12 Plant Manager

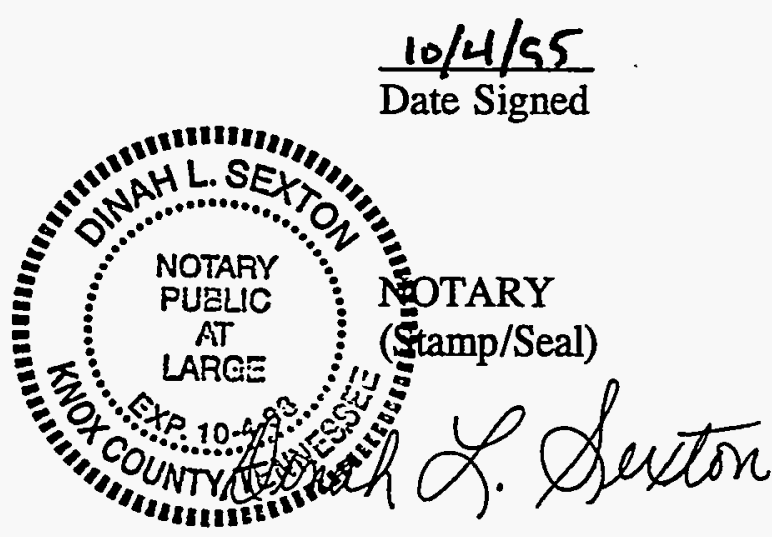

Note: Both signatures have been notarized per requirements. 


\subsection{INTRODUCTION}

\subsection{PURPOSE AND SCOPE}

The purpose of this document is to present potentiometric, groundwater quality, and vapor monitoring data required for site status monitoring of underground storage tank (UST) 0134-U at the Oak Ridge Y-12 Plant Building 9204-2 Site. Site status monitoring has been conducted at the site as part of a Monitoring Only program approved by the Tennessee Department of Environment and Conservation (TDEC) based on review and approval of Site Ranking (Site Ranking Form approved March 9, 1995). This document presents the results of the first semiannual site status monitoring that was performed in August and September 1995. Site status monitoring and preparation of this report have been conducted in accordance with the requirements of TDEC Rule 1200-1-15 and the.TDEC UST Reference Handbook, Second Edition (TDEC 1994) Technical Guidance Document (TGD) 007.

This document is organized into three sections. Section 1 presents introductory information relative to the site including the regulatory initiative and a site description. Section 2 includes the results of water level measurement and sampling of monitoring wells GW-204, GW-656, GW-805, GW-806, and GW-807. Section 3 presents data from vapor monitoring conducted in subsurface utilities present at the site.

\subsection{SITE DESCRIPTION}

The Building 9204-2 Site is located within the central portion of the Oak Ridge Y-12 Plant in Oak Ridge, Tennessee (Figure 1-1). This area is within the Protected Area of the Y-12 Plant, which is access restricted. The UST site is generally defined as the area directly east of Building 9204-2 and southwest of Building 9720-30 (Figure 1-2). The site was previously the location of a gasoline UST used to fuel an emergency generator at Building 9204-2. The tank has been excavated and removed from the site.

The UST was a 117-gallon gasoline tank that was first suspected of leaking in 1988. Tank 0134-U was excavated on August 26,1988, and several small holes were observed in the tank wall during removal. Initial Abatement/Tank Removal and Site Investigation/Environmental Assessment sampling indicated no presence of petroleum contamination in soil above applicable TDEC Closure Action Levels, but petroleum contamination of groundwater above applicable TDEC Closure Action Levels was identified. A Corrective Action Plan (CAP) for groundwater remediation was prepared and approved, and Baseline Monitoring was performed in August 1993 in support of corrective action. Baseline monitoring data were submitted to TDEC in March 1994 as part of a Closure Report. Additional soil and groundwater samples were collected to support Site Ranking before determining the disposition of the site. These samples indicated that contaminant concentrations were sufficiently low and contaminant exposure sufficiently limited in extent to qualify for a Monitoring Only program in lieu of active remediation. 


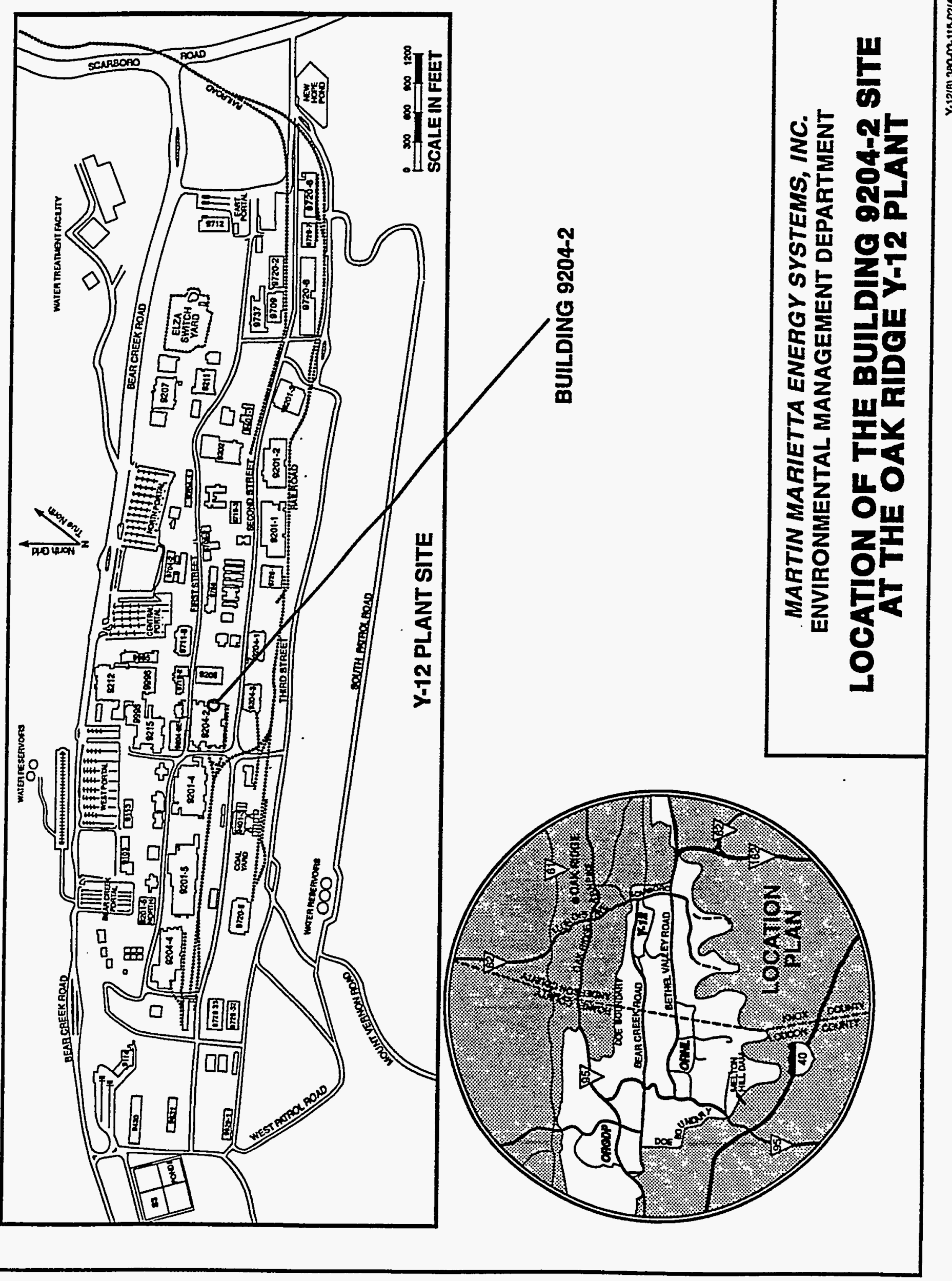




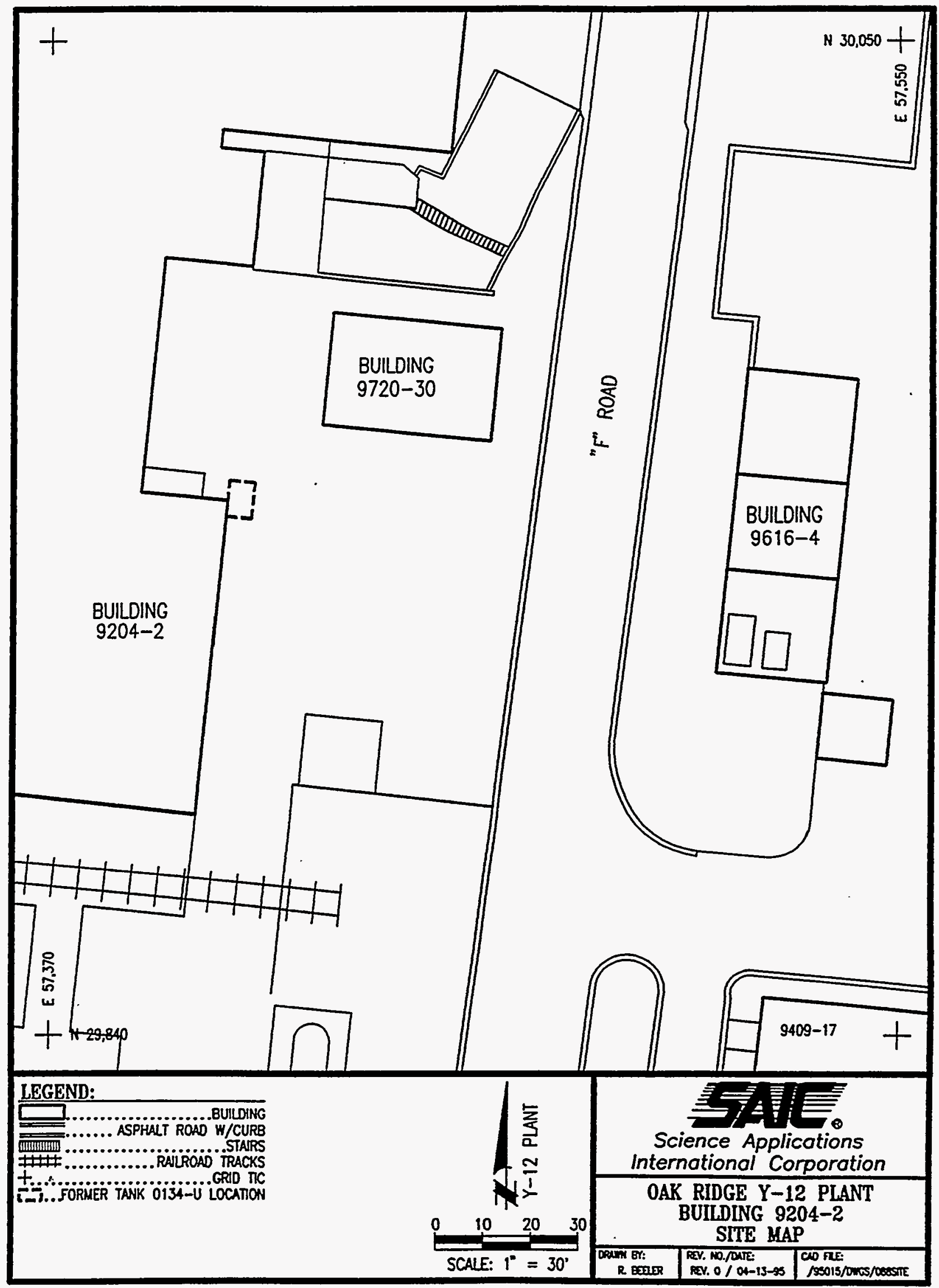

Figure 1-2. Building 9204-2 Site Map. 
The topography of the Building 9204-2 Site gently decreases in elevation from northwest to southeast across the facility. A surface water and groundwater divide coincident with the trace of Upper East Fork Poplar Creek (UEFPC) lies approximately $700 \mathrm{ft}$ southeast of the site. Given the nature of the surface topography in the vicinity of the Building 9204-2 Site, any petroleum contamination resulting from past UST operations would be expected to generally migrate southeast away from the source area. 


\subsection{GROUNDWATER MONITORING}

\subsection{GROUNDWATER MEASUREMENT, SAMPLE COLLECTION, AND ANALYSIS}

\subsubsection{Well Locations}

As directed by TDEC, all existing monitoring wells at the site have been measured and sampled as part of the Monitoring Only program. These wells are GW-204, GW-656, GW-805, GW-806, and GW-807. The locations of these wells are presented in Figure 2-1. Well installation reports and construction details for monitoring wells GW-204 and GW-656 are presented in the CAP for the Site [Corrective Action Plan for Underground Storage Tank 0134U at the Building 9204-2 Site, Appendix C, Y/SUB-92-99928C/4 (Energy Systems 1992)]. Well installation reports and construction details for monitoring wells GW-805, GW-806, and GW-807 that were installed in July 1993, are presented in the Closure Report for the Site [Closure Report for Underground Storage Tank 0134U, Building 9204-2, Appendix B, Y/SUB/94-99069C/Y15/5 (Energy Systems 1994)].

\subsubsection{Groundwater Measurement and Sampling}

All groundwater monitoring wells at the Building 9204-2 Site were measured for water level and sampled for the applicable petroleum constituents on September 7, 1995 as part of site status monitoring. All wells were measured for static water level and purged prior to sampling. All monitoring wells were purged of three well volumes except well GW-204, which was purged to dryness after 1.2 well volumes. Field measurement of $\mathrm{pH}$, conductivity, temperature, and dissolved oxygen was conducted during purging to ensure representativeness for sampling. Wells GW-805 and GW-807 demonstrated elevated water temperatures, but all other parameters were generally consistent across the site. Well GW-204 was allowed to recover prior to sampling. The wells were sampled for analysis, using a bailer, and then collected into preprepared bottles. No measurable free product or odors were encountered during water level measurement or sampling in any of these wells.

\subsubsection{Sample Analysis}

Groundwater samples were analyzed for total petroleum hydrocarbons-gasoline range organics (TPH-GRO), and for benzene, toluene, ethylbenzene, and xylenes (BTEX) at the Y-12 Plant Environmental Laboratory (a TDEC Division of UST-approved laboratory). Analytical laboratory reports for groundwater sampled during site status monitoring (9/95) are included in Appendix A. 


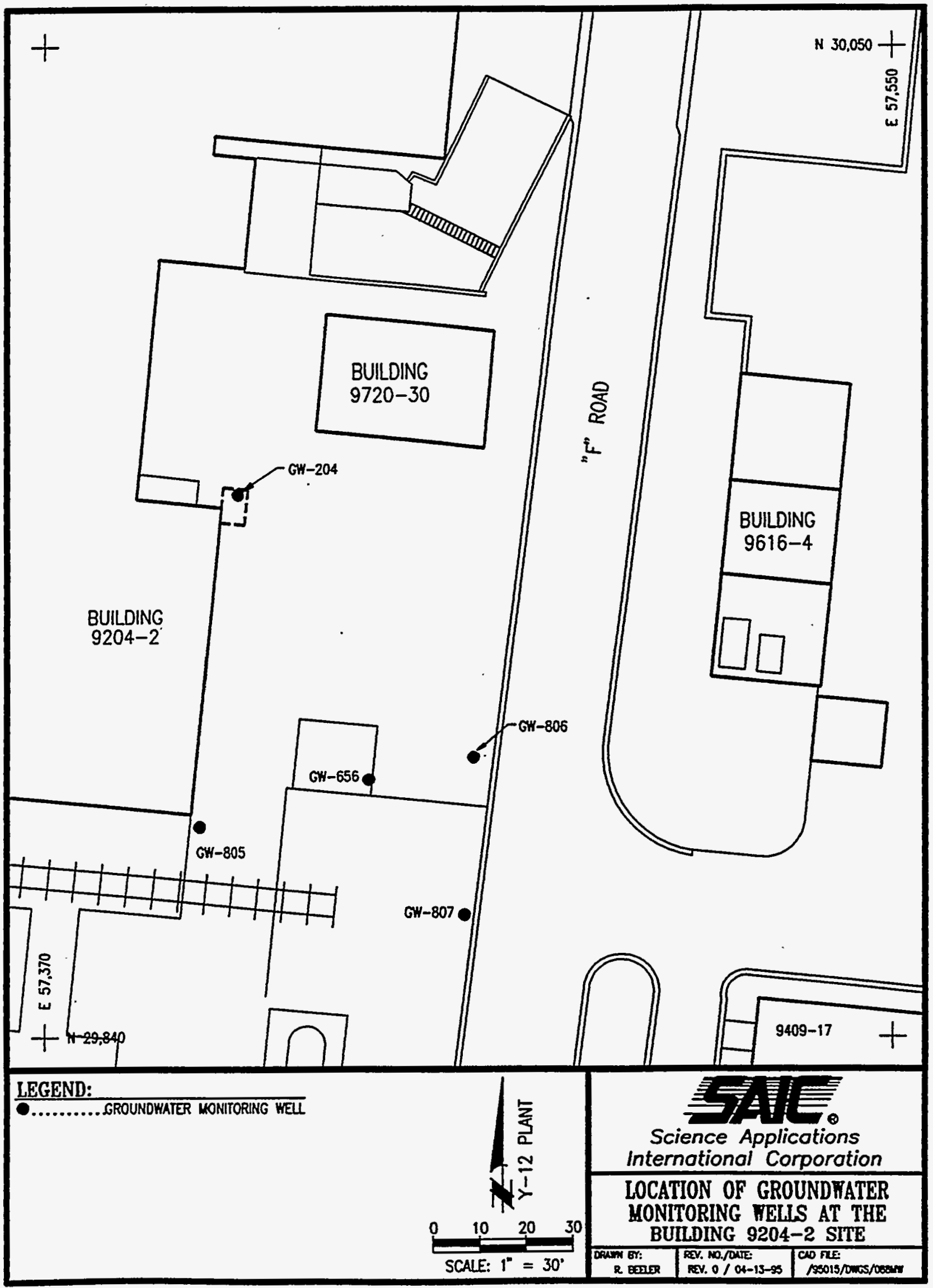

Figure 2-1. Location of Groundwater Monitoring Wells at the Building 9204-2 Site. 


\subsection{POTENTIOMETRIC DATA}

Potentiometric data for monitoring wells at the Building 9204-2 Site from site status monitoring (9/95) and comprehensive monitoring (3/95) measurement events are presented in Table 2-1. Figures 2-2 and 2-3 present potentiometric contour maps from these two periods. These figures indicate the presence of an irregular potentiometric surface with a generally easterly gradient. The apparent easterly deflection of the potentiometric gradient at the site may be due to small differences in head between unconsolidated and weathered bedrock wells and the degree of urbanization in this portion of the Y-12 Plant. The 800-series wells at the site were all completed in unconsolidated material at shallow depths [9.6-12.2 ft below ground surface (BGS)], whereas GW-204 and GW-656 were completed in weathered bedrock at 17.3 and $20.7 \mathrm{ft}$ BGS, respectively.

The seasonal difference between the potentiometric surfaces is primarily attributable to the drop in water level in well GW-807. The other wells at the site remained very consistent during this period. The apparent seasonal change between a northeasterly flow direction and a southeasterly flow direction is likely a local perturbation attributable, at least in part, to the distribution and depths of the wells being monitored. Studies of the Y-12 Plant hydrogeology indicate that an overall south/southeasterly hydraulic gradient is present in the unconsolidated and bedrock intervals at the Building 9204-2 Site (HSW 1994). Seasonal variation in groundwater elevations is small, but does appear to produce a localized southerly gradient in the northern portion of the site during wetter weather and a generally southeastern gradient in drier weather. Overall, groundwater flow at the site is to the east/southeast toward Upper East Fork Poplar Creek.

\subsection{GROUNDWATER ANALYTICAL DATA}

Analytical results for groundwater sampled at the site during site status and comprehensive monitoring, site ranking, and baseline sampling are presented in Table 2-2. Analytical results indicate the presence of TPH-GRO groundwater contamination above the applicable TDEC Closure Action Level of $1.0 \mathrm{ppm}$ TPH at a single monitoring well (GW-656). Monitoring well GW-806 indicates the presence of TPH-GRO contamination above the analytical quantitation limit but well below the applicable TDEC Closure Action Level. Since GW-656 is bounded by the remaining four monitoring wells, the horizontal extent of TPH-GRO contamination in groundwater is well constrained. The level of TPH-GRO contamination is low, and the concentration of contamination has consistently fallen off over the past year. The extent of groundwater contamination has remained relatively stable at the site throughout the period monitored. This is consistent with previous monitoring results and the calculated hydraulic gradient, velocity, and conductivity from slug testing of wells GW-204 and GW-656 (Energy Systems 1992). 


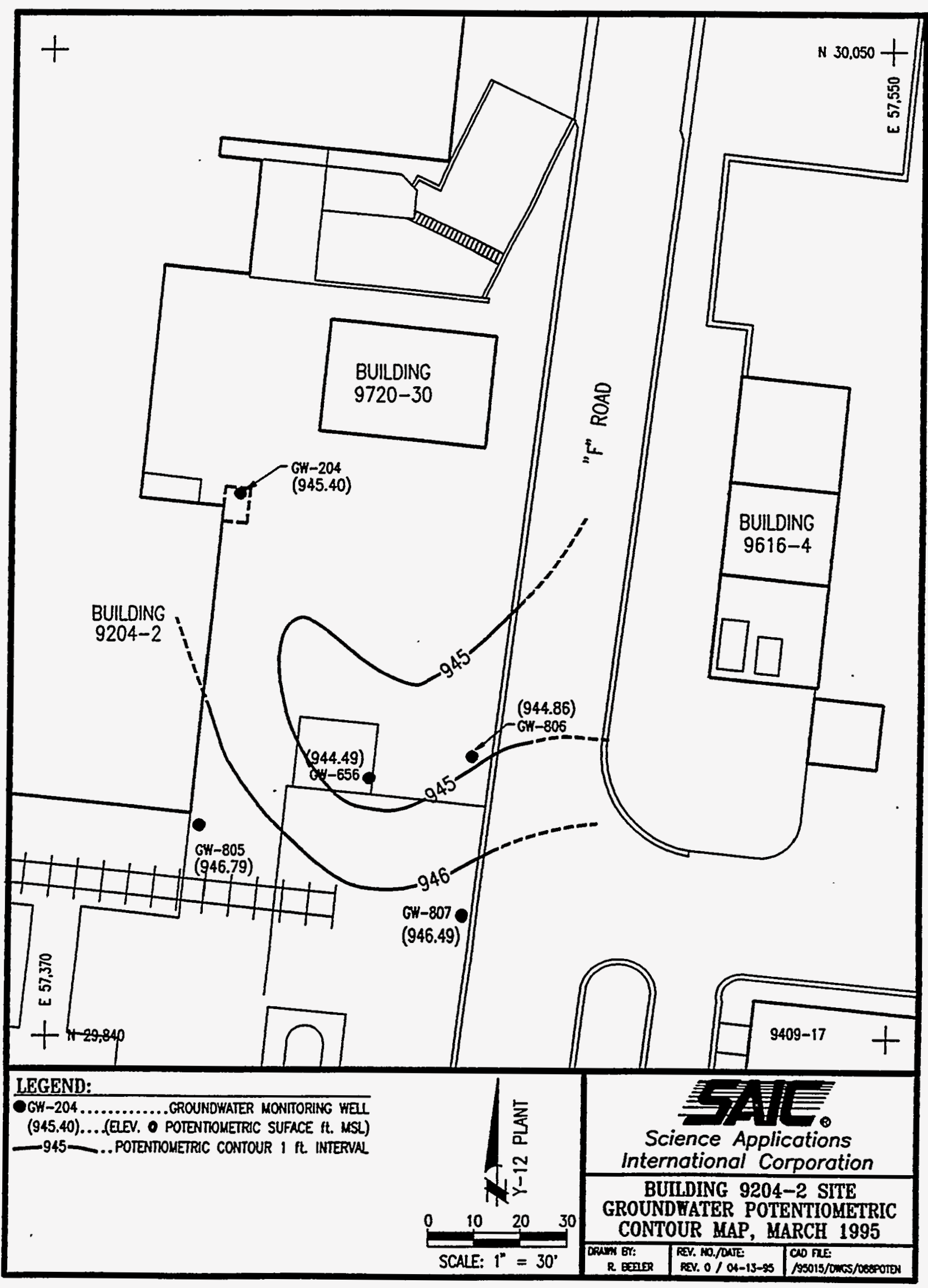

Figure 2-2. Building 9204-2 Site Groundwater Potentiometric Contour Map, March 1995. 


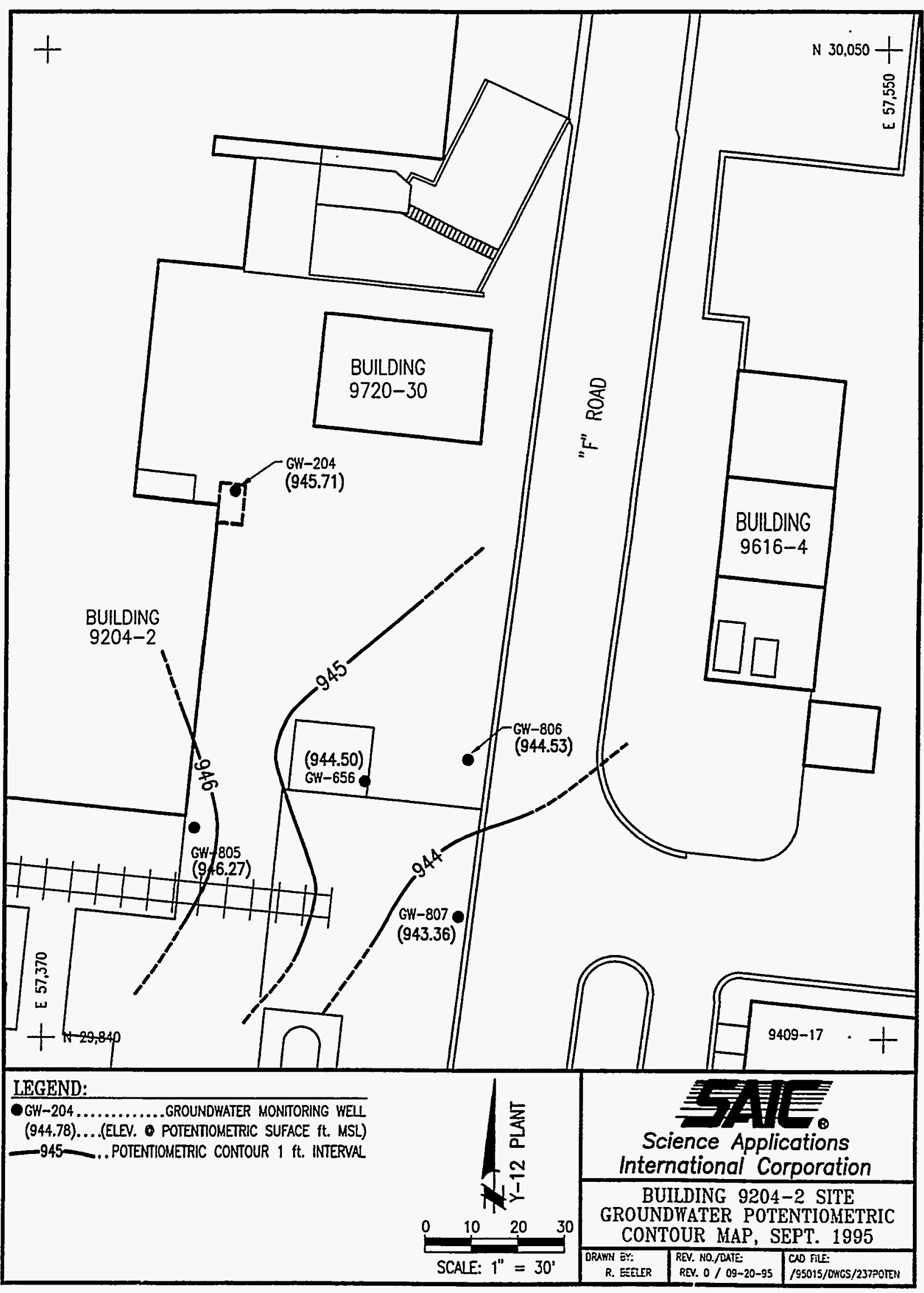

Figure 2-3. Building 9204-2 Site Groundwater Potentiometric Contour Map, September 1995. 
The analytical results do not indicate the presence of benzene contamination in any of the wells during site status monitoring. Trace amounts of benzene above the analytical quantitation limit but below the most stringent TDEC Closure Action Level of $0.07 \mathrm{ppm}$ were detected in monitoring wells GW-204 and GW-656 during the earliest sampling event. However, levels of benzene in groundwater have remained below the analytical quantitation limit through the remainder of the period monitored. In general, it is expected that contaminant levels will fall off slowly as contaminant degradation proceeds because of the slow migration and limited mixing of the groundwater at the site. 
Table 2-1. Water Level Measurements at the Building 9204-2 Site for the Periods of September 1995 and March 1995

\begin{tabular}{cccccc}
\hline $\begin{array}{c}\text { Monitoring } \\
\text { well number }\end{array}$ & $\begin{array}{c}\text { Date } \\
\text { measured }\end{array}$ & $\begin{array}{c}\text { Total well } \\
\text { depth } \\
\text { (ft-BGS) }\end{array}$ & $\begin{array}{c}\text { Top of } \\
\text { casing } \\
\text { (ft-MSL) }\end{array}$ & $\begin{array}{c}\text { Top of casing } \\
\text { to water level } \\
\text { (ft-BTOC) }\end{array}$ & $\begin{array}{c}\text { Potentiometric } \\
\text { surface elevation } \\
\text { (ft-MSL) }\end{array}$ \\
\hline GW-204 & $9 / 7 / 95$ & 20.3 & 955.47 & 9.76 & 945.71 \\
& $3 / 29 / 95$ & & & 10.07 & 945.40 \\
GW-656 & $9 / 7 / 95$ & 20.6 & 954.90 & 10.40 & 944.50 \\
& $3 / 29 / 95$ & & & 10.41 & 944.49 \\
GW-805 & $9 / 7 / 95$ & 11.6 & 955.02 & 8.75 & 946.27 \\
& $3 / 29 / 95$ & & & 8.23 & 946.79 \\
GW-806 & $9 / 7 / 95$ & 11.5 & 951.95 & 7.42 & 944.53 \\
& $3 / 29 / 95$ & & & 7.09 & 944.86 \\
GW-807 & $9 / 7 / 95$ & 14.0 & 955.36 & 12.0 & 943.36 \\
& $3 / 29 / 95$ & & & 8.87 & 946.49 \\
\hline
\end{tabular}

Notes:

BGS - below ground surface

MSL - mean sea level

BTOC - below top of casing 
Table 2-2. Analytical Results for Groundwater Samples Collected During Site Status and Comprehensive Monitoring, Site Ranking, and Baseline Sampling

\begin{tabular}{|c|c|c|c|c|c|c|}
\hline Sampling event & $\begin{array}{c}\text { Sampling } \\
\text { date }\end{array}$ & $\begin{array}{c}\text { TPH-GRO' } \\
(\mathrm{ppm})\end{array}$ & $\begin{array}{c}\text { Benzene } \\
\text { (ppm) }\end{array}$ & $\begin{array}{l}\text { Ethylbenzene } \\
\text { (ppm) }\end{array}$ & $\begin{array}{c}\text { Toluene } \\
\text { (ppm) }\end{array}$ & $\begin{array}{c}\text { Xylenes } \\
\text { (ppm) }\end{array}$ \\
\hline \multicolumn{7}{|c|}{$G W-204$} \\
\hline $\begin{array}{l}\text { Site status } \\
\text { monitoring }\end{array}$ & $9-7-95$ & $<0.100^{2}$ & $0.010 U^{3}$ & $0.010 \mathrm{U}$ & $0.010 \mathrm{U}$ & $<0.010$ \\
\hline $\begin{array}{l}\text { Comprehensive } \\
\text { monitoring }\end{array}$ & $3-29-95$ & 0.150 & $<0.010$ & $<0.010$ & $<0.010$ & $0.010 \mathrm{U}$ \\
\hline Site ranking & $9-2-94$ & $<0.100$ & $0.010 \mathrm{U}$ & $<0.010$ & $<0.010$ & $0.010 \mathrm{U}$ \\
\hline Baseline sampling & $8-30-93$ & 0.180 & 0.004 & 0.009 & $0.001 U$ & 0.007 \\
\hline \multicolumn{7}{|c|}{$G W-656$} \\
\hline $\begin{array}{l}\text { Site status } \\
\text { monitoring }\end{array}$ & $9-7-95$ & $* 1.800$ & $<0.010$ & $0.010 \mathrm{U}$ & $0.010 U$ & $0.010 \mathrm{U}$ \\
\hline $\begin{array}{l}\text { Comprehensive } \\
\text { monitoring }\end{array}$ & $3-29-95$ & $* 2.300$ & $<0.010$ & $0.010 \mathrm{U}$ & $0.010 \mathrm{U}$ & $<0.010$ \\
\hline Site ranking & $9-2-94$ & $* 2.700 D^{4}$ & $<0.010$ & $0.010 \mathrm{U}$ & $0.010 \mathrm{U}$ & $0.010 \mathrm{U}$ \\
\hline Baseline sampling & $8-30-93$ & 0.830 & 0.003 & $0.001 U$ & $0.001 \mathrm{U}$ & $0.001 \mathrm{U}$ \\
\hline \multicolumn{7}{|c|}{$G W-805$} \\
\hline $\begin{array}{l}\text { Site status } \\
\text { monitoring }\end{array}$ & $9-7-95$ & $<0.100$ & $0.010 \mathrm{U}$ & $0.010 \mathrm{U}$ & $0.010 \mathrm{U}$ & $0: 010 \mathrm{U}$ \\
\hline $\begin{array}{l}\text { Comprehensive } \\
\text { monitoring }\end{array}$ & $3-29-95$ & $<0.100$ & $0.010 \mathrm{U}$ & $0.010 \mathrm{U}$ & $0.010 \mathrm{U}$ & $0.010 \mathrm{U}$ \\
\hline Site ranking & $9-2-94$ & 0.280 & $0.010 \mathrm{U}$ & $0.010 \mathrm{U}$ & $0.010 \mathrm{U}$ & $0.010 \mathrm{U}$ \\
\hline Baseline sampling & $8-30-93$ & $0.100 \mathrm{U}$ & $0.001 \mathrm{U}$ & $0.001 \mathrm{U}$ & $0.001 \mathrm{U}$ & $0.001 \mathrm{U}$ \\
\hline \multicolumn{7}{|c|}{$G W-806$} \\
\hline $\begin{array}{l}\text { Site status } \\
\text { monitoring }\end{array}$ & $9-7-95$ & 0.110 & $0.010 \mathrm{U}$ & $0.010 \mathrm{U}$ & $0.010 \mathrm{U}$ & $0.010 \mathrm{U}$ \\
\hline $\begin{array}{l}\text { Comprehensive } \\
\text { monitoring }\end{array}$ & $3-29-95$ & 0.160 & $0.010 \mathrm{U}$ & $0.010 \mathrm{U}$ & $0.010 \mathrm{U}$ & $0.010 \mathrm{U}$ \\
\hline Site ranking & $9-2-94$ & 0.290 & $0.010 \mathrm{U}$ & $0.010 \mathrm{U}$ & $<0.010$ & $0.010 \mathrm{U}$ \\
\hline Baseline sampling & $8-30-93$ & 0.160 & $0.001 U$ & $0.001 \mathrm{U}$ & $0.001 \mathrm{U}$ & $0.001 \mathrm{U}$ \\
\hline \multicolumn{7}{|c|}{$G W-807$} \\
\hline $\begin{array}{l}\text { Site status } \\
\text { monitoring }\end{array}$ & $9-7-95$ & $<0.100$ & $0.010 \mathrm{U}$ & $0.010 \mathrm{U}$ & $0.010 \mathrm{U}$ & $0.010 \mathrm{U}$ \\
\hline $\begin{array}{l}\text { Comprehensive } \\
\text { monitoring }\end{array}$ & $3-29-95$ & $<0100$ & $0.010 \mathrm{U}$ & $0.010 \mathrm{U}$ & $0.010 \mathrm{U}$ & $0.010 \mathrm{U}$ \\
\hline Site ranking & $9-2-94$ & $<0.100$ & $0.010 \mathrm{U}$ & $0.010 \mathrm{U}$ & $0.010 U$ & $0.010 \mathrm{U}$ \\
\hline Baseline sampling & $8-30-93$ & $0.100 \mathrm{U}$ & $0.001 \mathrm{U}$ & $0.001 \mathrm{U}$ & $0.001 \mathrm{U}$ & $0.001 \mathrm{U}$ \\
\hline
\end{tabular}

1 TPH-GRO - Total Petroleum Hydrocarbons-Gasoline Range Organics.

$2<$ - Contaminant was not detected above quantitation limit during the analysis.

${ }^{3} \mathrm{U}$ - Contaminant was not detected above quantitation limit during the analysis.

$4 \mathrm{D}$ - Sample was diluted during analysis.

${ }^{5}$ NS - Not sampled

* Denotes contamination above the applicable closure action levels for the site. 


\subsection{VAPOR MONITORING}

\subsection{MONITORING METHODS AND LOCATIONS}

Vapor monitoring as part of site status monitoring was conducted at six access points along subsurface stormwater and sewer drainage lines in the vicinity of the Building 9204-2 Site. These points correspond to the points measured during comprehensive monitoring, and will be used throughout the Monitoring Only Program. However, none of the subsurface utilities present at the site cross the groundwater plume defined by the most recent data. The locations of vapor monitoring locations are illustrated in Figure 3-1.

At each location, the utility line and/or valve pit atmosphere was monitored using direct reading instruments. Organic vapors were measured using an organic vapor meter, and oxygen and lower explosive limit (LEL) were monitored with an MSA-260.

\subsection{VAPOR MONITORING RESULTS}

The results of site status vapor monitoring conducted August 31, 1995 at the Building 9204-2 Site are presented in Table 3-1. Measured oxygen percentages are within the range of normal air concentrations. LEL readings of $0 \%$ indicate that an explosion hazard does not exist within any of the monitored utilities. Organic vapor readings of 0.000 to $0.001 \mathrm{ppm}$ indicate no concentrations of volatile organic compounds above background are present in the utility line atmospheres.

Table 3-1. Vapor Monitoring Results for the Building 9204-2 Site, August 31, 1995

\begin{tabular}{cccc}
\hline $\begin{array}{c}\text { Sampling } \\
\text { location }\end{array}$ & $\begin{array}{c}\mathrm{O}_{2} \\
\%\end{array}$ & $\begin{array}{c}\text { LEL } \\
\%\end{array}$ & $\begin{array}{c}\text { Organic vapors } \\
(\mathrm{ppm})\end{array}$ \\
\hline B-1001 & 20.8 & 0 & 0.001 \\
B-1002 & 20.8 & 0 & 0.001 \\
B-1003 & 20.8 & 0 & 0.000 \\
B-1004 & 20.8 & 0 & 0.000 \\
B-1005 & 20.8 & 0 & 0.001 \\
B-1006 & 20.8 & 0 & 0.000 \\
\hline
\end{tabular}




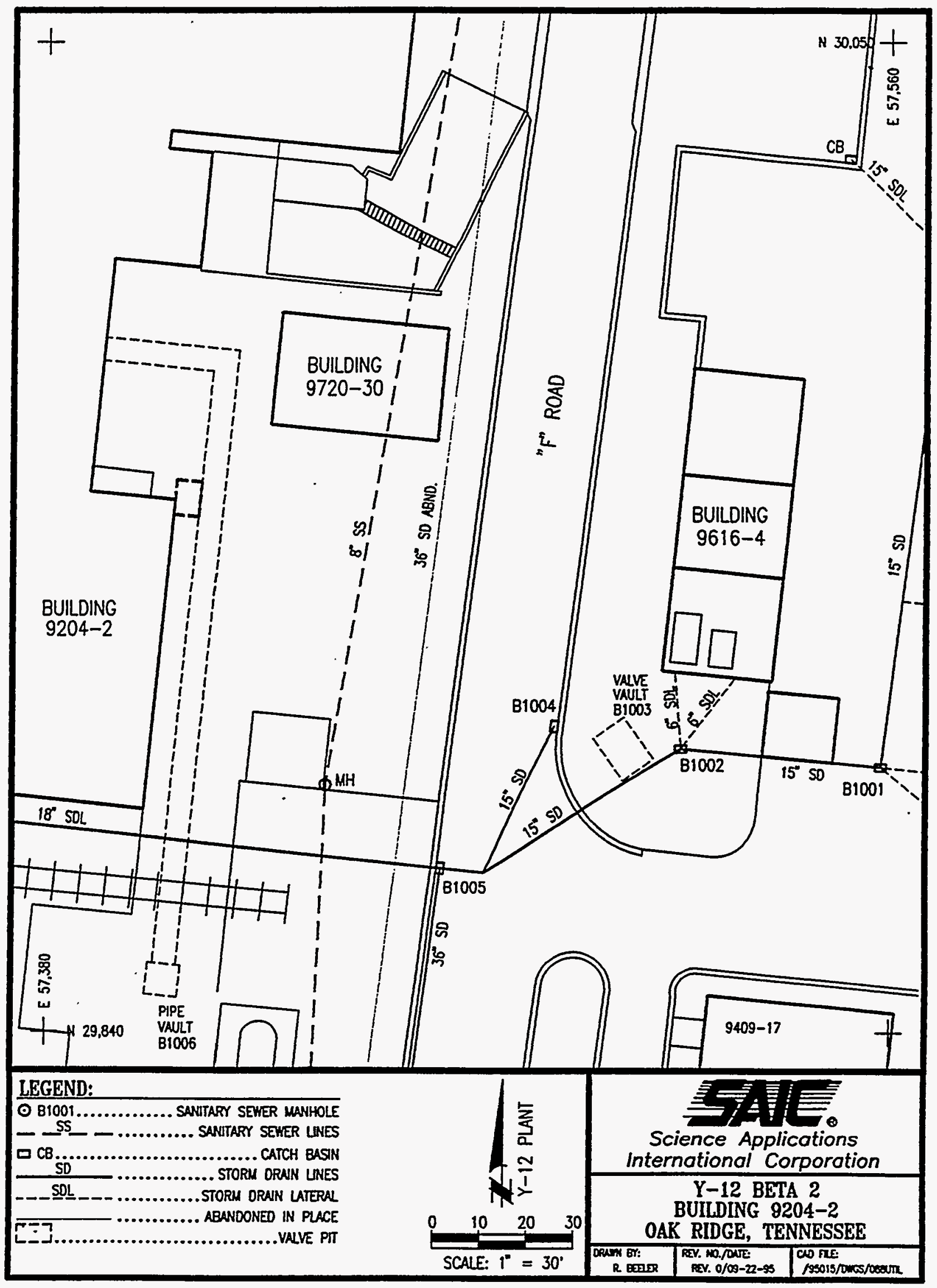

Figure 3-1. Organic Vapor Monitoring Points at the Building 9204-2 Site. 


\section{REFERENCES}

Energy Systems (Martin Marietta .Energy Systems, Inc.) 1992. Corrective Action Plan for Underground Storage Tank 0134U at the Building 9204-2 Site, Y/SUB-92-99928C/4.

Energy Systems 1994. Closure Report for Underground Storage Tank 0134-U, Building 9204-2, Appendix B, Y/SUB/94-99069C/Y15/5.

HSW Environmental Consultants, Inc. 1994. Calendar Year 1993 Groundwater Quality Report for the Upper East Fork Poplar Creek Hydrogeologic Regime, Y-12 Plant, Oak Ridge, Tennessee, Y/SUB/94-EAQ10C/2/P1.

TDEC (Tennessee Department of Environment and Conservation) 1994. Underground Storage Tank Reference Handbook, Second Edition. 
APPENDIX A

LABORATORY ANALYTICAL RESULTS FOR SITE STATUS MONITORING

GROUNDWATER SAMPLING 


\section{UNCLASSIFIED}

OFFICIAL REPORT

\section{MITTER} Irman, Donald Edwa

IE SAMPLED: 09/07/95

TE RECEIVED: 09/08/95

IPLER: 13303

\section{ADDRESS}

Building 9115 MS 8219

DATE NEEDED: 09/22/95

DATE COMPLETED: 09/18/95

SAMPLE DESCRIPTION: H2O GRAB $\frac{\text { CUSTOMER ID }}{\text { A1G774-001 }} \quad \frac{\text { REQ NO }}{\text { A1G774 }} \quad \frac{\text { SAMPLE NO }}{\text { E952510008 }}$ LOCATION: GH 204 PROJECT COOE:

IMENTS: FACILITY ID: 0-010117; UST PROGRAM 9204-2 WELLS

iT: BTEX iP MTH:
VOA Analysis, BTEX Compounds (SW846 8020) PROC MTH: SH846 8020 PHASE: THIS TEST WAS CANCELLED BY W6O
HTC STATUS 8601 APPROVED CHARGE \#: S2205F28 CASE: U03117
FIHAL APPROVAL:

1 OF 1

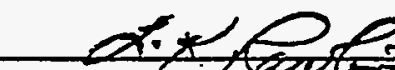

REPLICATE: ' 1 STATUS: CANCELLED

TIME ANALYZED: $\quad$ APPROVER:

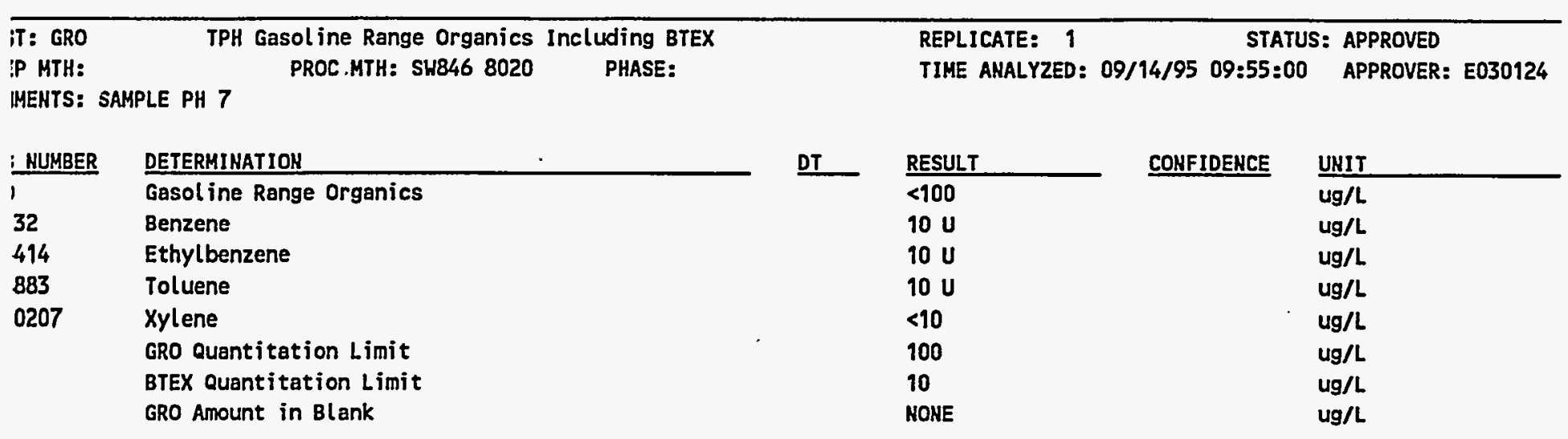




\section{UNCLASSIFIED}

OFFICIAL REPORT

$1 / 18 / 95$ 15:19:03

\section{IBMITTER}

Ihrman, Donald Edwa

ITE SAMPLED: 09/07/95 11:37:00

TE RECEIVED: 09/08/95

MPLER: 13303

MMENTS: FACILITY ID: 0-010117; UST PROGRAM 9204-2 WELLS
Y-12 ANALYTICAL SERVICES ORGANIZATION

PAGE 1 OF 1

\begin{tabular}{|c|c|c|c|c|}
\hline CUSTOMER ID & REO NO & SAMPLE NO & MTC & STATUS \\
\hline A1G774003 & A1G774 & $E 952510010$ & 8601 & APPROVED \\
\hline LOCATIOH: GW-656 & & & CHARG & S2205F28 \\
\hline PROJECT CODE: & & & CASE: & 3117 \\
\hline
\end{tabular}

FINAL APPROVAL:

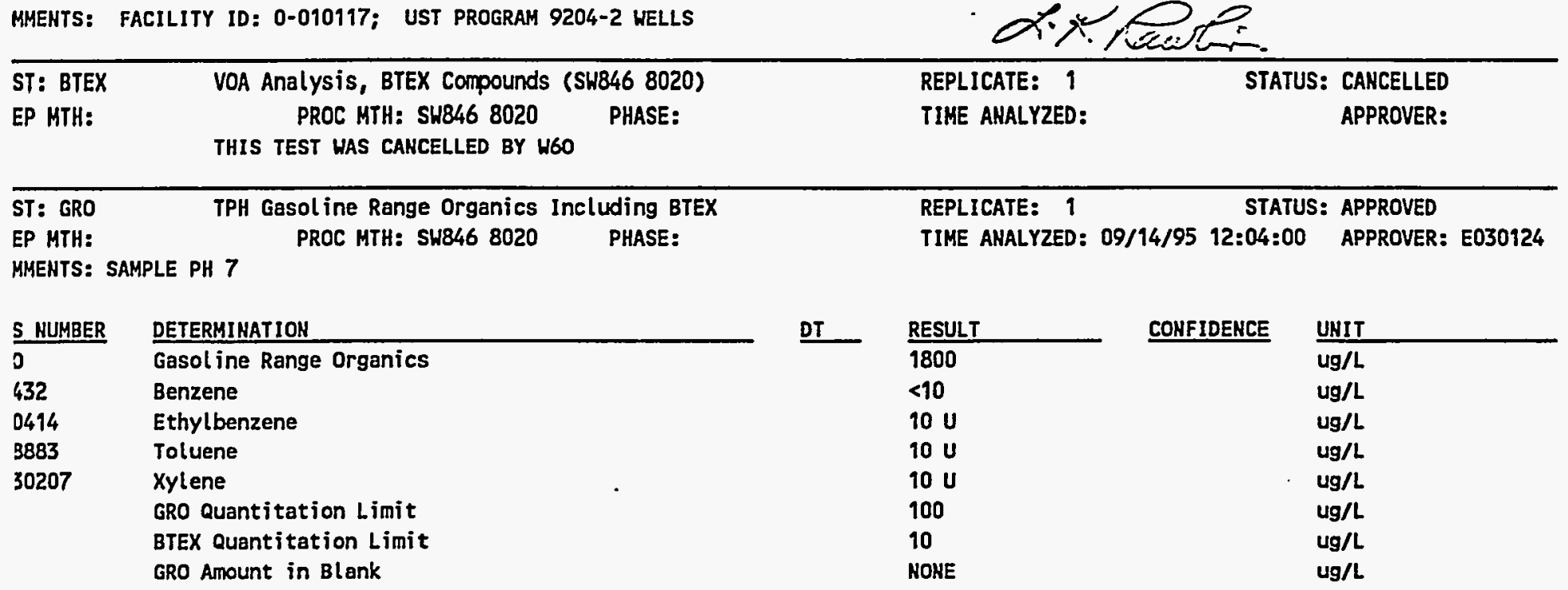


OFFICIAL REPORT

$1 / 18 / 9515: 18: 48$

\section{BHITTER}

hrman, Donald Edwa

TE SAMPLED: 09/07/95 10:39:00

TE RECEIVED: 09/08/95

MPLER: 13303
Y-12 ANALYTICAL SERVICES ORGANIZATION
PAGE 1 OF 1

MMENTS: FACILITY ID: 0-010117; UST PROGRAM 9204-2 WELLS

VOA Analysis, BTEX Compounds (SW846 8020) $\frac{\text { CUSTOMER ID }}{\text { A1G774002 }} \quad \frac{\text { REQ NO }}{\text { A1G774 }} \quad \frac{\text { SAMPLE NO }}{\text { E952510009 }}$

MTC

STATUS

LOCATION: GH 805

8601 APPROVED

DATE NEEDED: $09 / 22 / 95$

DATE COMPLETED: 09/18/95

PROJECT CODE:

CHARGE \#: S2205F28

SAMPLE DESCRIPTION: H2O GRAB

FINAL APPROVAL:

CASE: U03117

EP NTH: PROC MTH: SH846 8020 PHASE:

REPLICATE: 1

TIME ANALYZED:
STATUS: CANCELLED

APPROVER:

THIS TEST WAS CANCELLED BY $W 60$

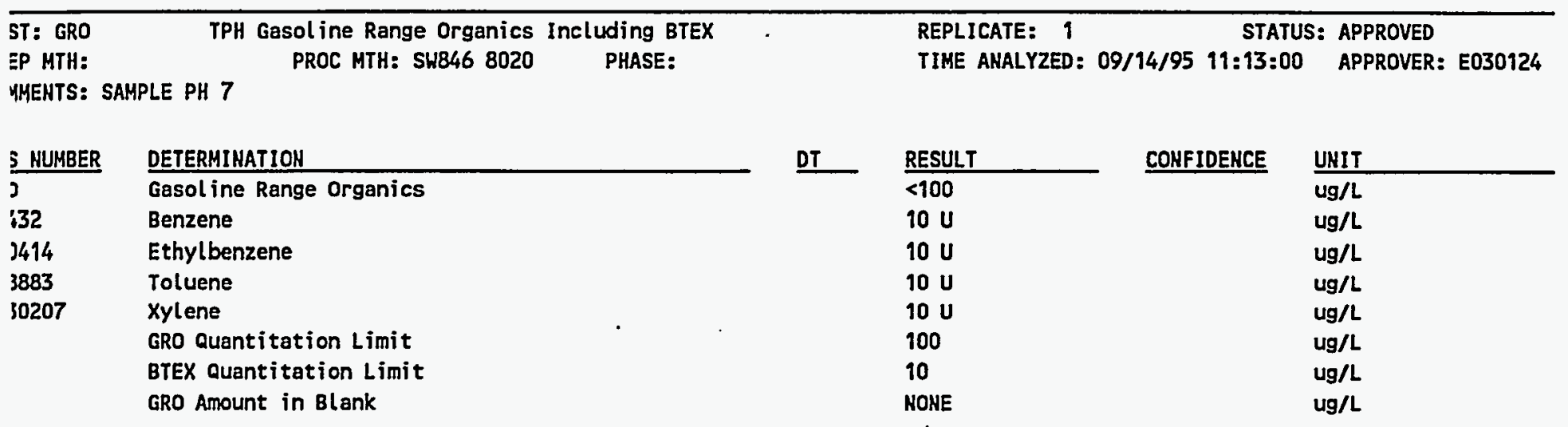




\section{UNCLASSIFIED}

OFFICIAL REPORT

\section{BMITTER}

hrman, Donald Edwa

TE SAMPLED: 09/07/95 $13: 25: 00$

TE RECEIVED: 09/08/95

SPLER: 13303

AMENTS: FACILITY 10: 0-010117; UST PROGRAM 920402 WELLS

$\begin{array}{lllll}\text { CUSTOMER ID } & \frac{\text { REQ NO }}{\text { A1G774 }} & \frac{\text { SAMPLE NO }}{\text { E952510012 }} & & \begin{array}{l}\text { MTC } \\ \text { A1G01 }\end{array} \frac{\text { STATUS }}{\text { APPROVED }} \\ \text { LOCATION: GH-807 } & & & \text { CHARGE \#: S2205F28 } \\ \text { PROJECT CODE: } & & \text { CASE: U03117 }\end{array}$

FINAL APPROVAL:

\begin{tabular}{|c|c|c|c|c|}
\hline $\begin{array}{l}\text { ST: BTEX } \\
\text { :P MTH: }\end{array}$ & $\begin{array}{l}\text { VOA Analysis, BTEX Compounds (SW846 8020) } \\
\text { PROC MTH: SH846 } 8020 \text { PHASE: } \\
\text { THIS TEST WAS CANCELLED BY W6O }\end{array}$ & & $\begin{array}{l}\text { REPLICATE: } 1 \\
\text { TIME ANALYZED: }\end{array}$ & $\begin{array}{l}\text { CANCELLED } \\
\text { APPROVER: }\end{array}$ \\
\hline $\begin{array}{l}\text { IT: GRO } \\
\text { :P MTH: } \\
\text { IMENTS: 'S }\end{array}$ & $\begin{array}{l}\text { TPH Gasoline Range Organics including BTEX } \\
\text { PROC MTH: SH846 } 8020 \text { PHASE: } \\
\text { PLE PH } 7\end{array}$ & & $\begin{array}{l}\text { REPLICATE: } 1 \quad \text { STATUS: } \\
\text { TIME ANALYZED: } 09 / 15 / 95 \text { 08:54:00 }\end{array}$ & $\begin{array}{l}\text { APPROVED } \\
\text { APPROVER: E030124 }\end{array}$ \\
\hline I NUMBER & DETERMINATION & $\underline{\text { DT }}$ & CONFIDENCE & UNIT \\
\hline 1 & Gasoline Range Organics & & $<100$ & ug/L \\
\hline 132 & Benzene & & $10 \mathrm{U}$ & $u g / L$ \\
\hline 1414 & Ethylbenzene & & $10 \mathrm{U}$ & ug/L \\
\hline 1883 & Toluene & & $10 u$ & ug/L \\
\hline$; 0207$ & Xylene & & $10 \mathrm{U}$ & $u g / L$ \\
\hline & GRO Quantitation Limit & & 100 & $u g / L$ \\
\hline & BTEX Quantitation Limit & & 10 & $\mathrm{ug} / \mathrm{L}$ \\
\hline & GRO Amount in Blank & & NONE & ug/L \\
\hline
\end{tabular}


OFFICIAL REPORT

\begin{tabular}{|c|c|c|}
\hline BHITTER & ADDRESS & \\
\hline$\overline{\text { hrman, Donald Edwa }}$ & Building & MS 8219 \\
\hline TE SAMPLED: 09/07/95 & $09: 00: 00$ & DATE NEEDED: $09 / 22 / 95$ \\
\hline IE RECEIVED: 09/08/95 & & DATE COMPLETED: 09/12/95 \\
\hline APLER: 13303 & & SAMPLE DESCRIPTION: GRAB \\
\hline
\end{tabular}

MMENTS: UST PROGRAM 9204-2 HELLS

\begin{tabular}{|c|c|c|c|c|}
\hline CUSTOHER ID & REO NO & SAMPLE NO & MTC & STATUS \\
\hline A1G775001 & A1G775 & E952510013 & 8601 & APPROVED \\
\hline LOCATION: TR & ANK & & CHAR & S2205F28 \\
\hline
\end{tabular}

FINAL APPROVAL:

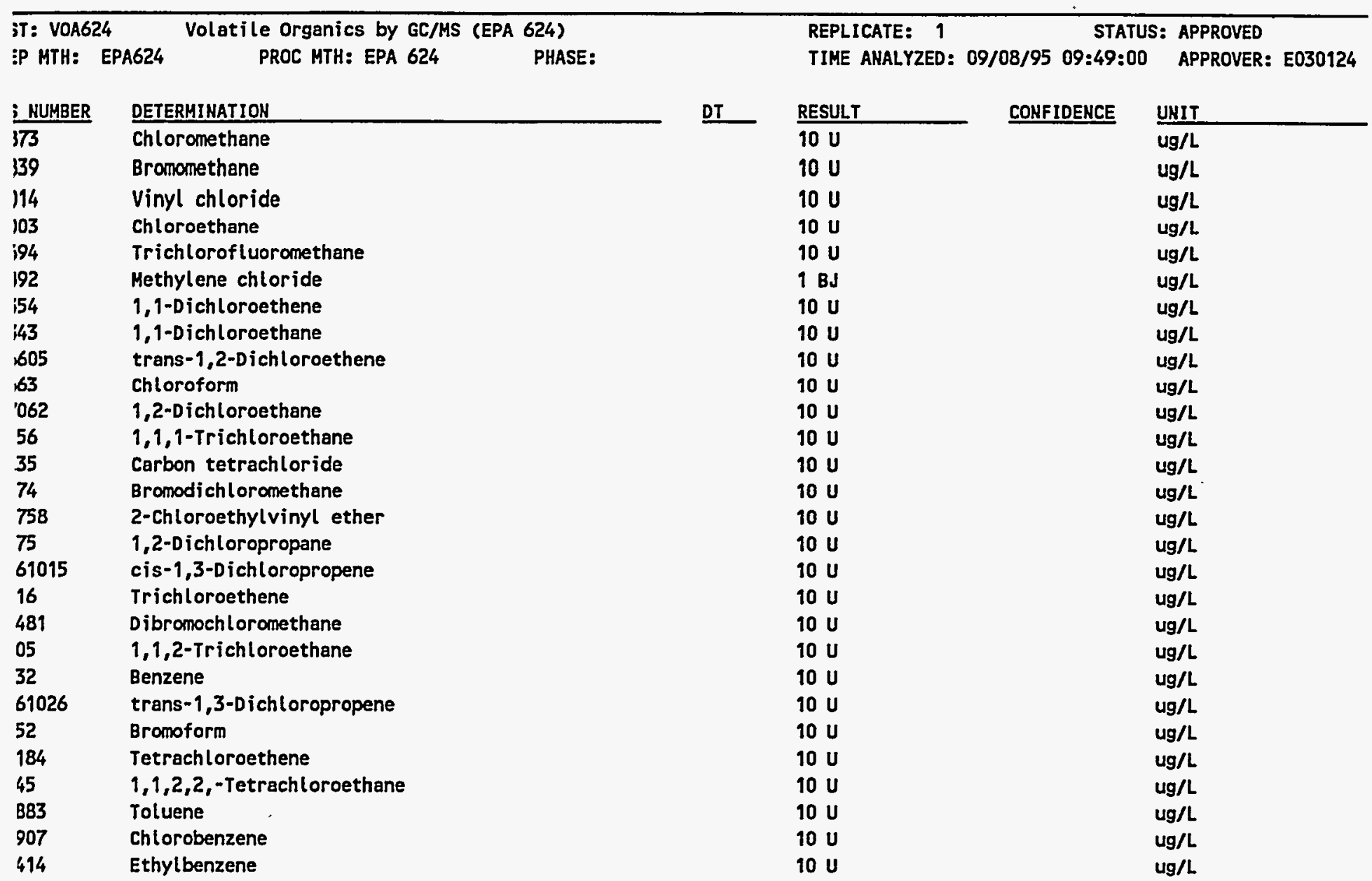




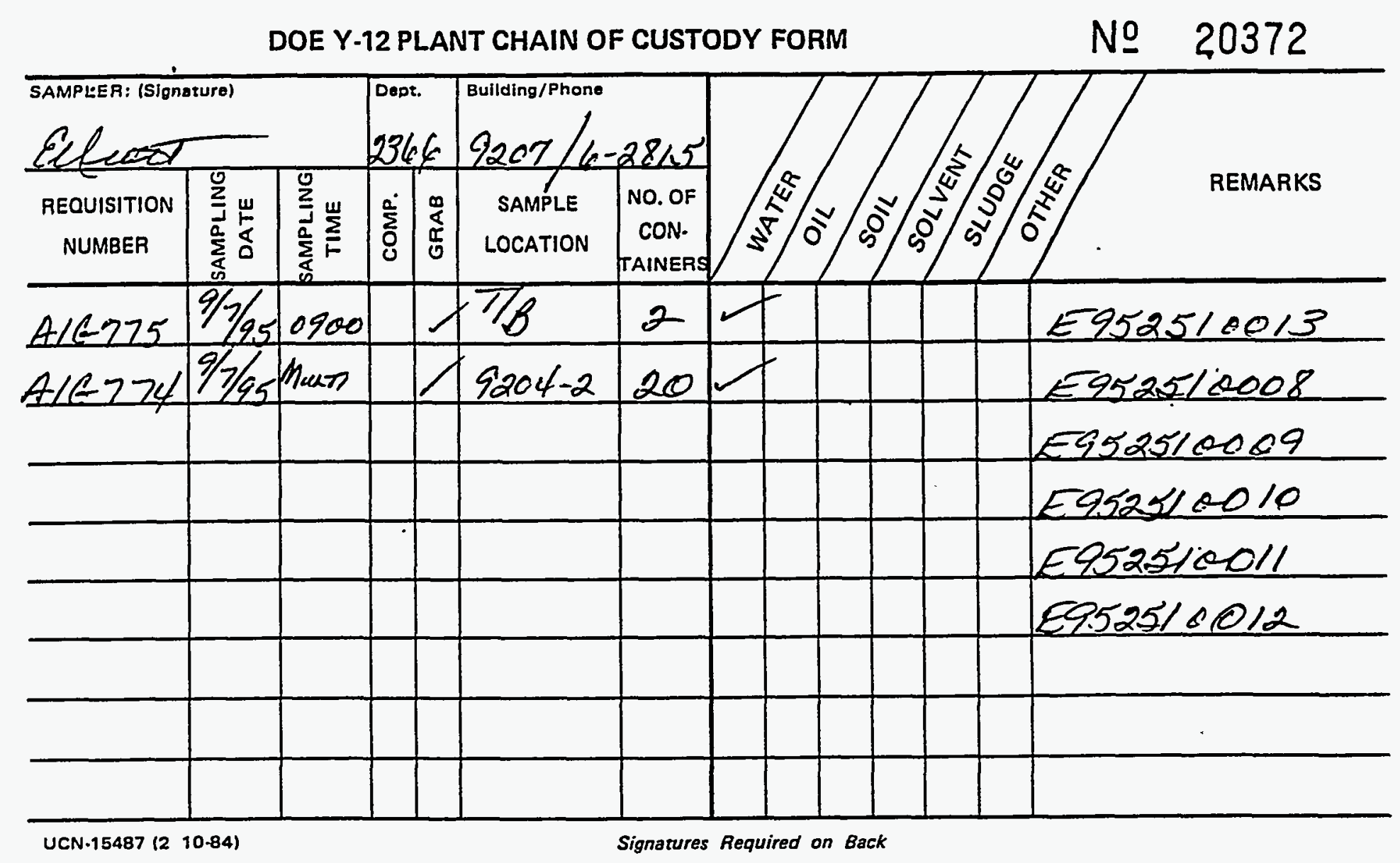

